Dialectologia 27 (2021), 175-187.

ISSN: 2013-2247

Received 27 April 2019.

Accepted 24 October 2019.

10.1344/Dialectologia2021.27.7

\title{
LEXICAL VARIATIONS OF JAVANESE USED BY THE TRANSMIGRANTS IN DHARMASRAYA REGENCY
}

\author{
Leo Nella RIZKI N, Nadra NADRA \& Noviatri NoVIATRI
}

Universitas Andalas *

nellaleo16@gmail.com/nadra@hum.unand.ac.id/noviatriyat@yahoo.com

\begin{abstract}
The aims of this study are to describe and to determine the percentage of lexical variations in the Javanese used by the transmigrants in Dharmasraya Regency. The data were collected using the observational and conversational method. Identity and dialectometry method was used to analyse the data. The results showed that Javanese in Dharmasraya Regency can be divided into four dialects, they are: Tebing Tinggi, Koto Laweh, Kurnia Koto Salak and Sitiung dialect. The Sitiung dialect can be divided into two subdialects, namely Sitiung and Pulau Mainan subdialect. These differences of dialects are caused by geographical factor, the distance between the points of observation, transportation, and communication. Javanese used in the daily conversation is different from Javanese used in the homeland or in Java Island, which does not have language level as known as unggah-ungguh. It happens due to the lack of mastery and understanding of the speakers about the concept.
\end{abstract}

\section{Keywords}

lexical, variation, Javanese, transmigrant, dialect

\footnotetext{
* Faculty of Humanities, Universitas Andalas, Limau Manis, Padang-25163, West Sumatra, Indonesia.
} 


\section{DIFERENCIAS LÉXICAS DEL JAVANÉS EN LOS EMIGRANTES \\ DE LA REGENCIA DE DHARMASRAYA}

\section{Resumen}

Los objetivos de este estudio son describir y determinar el porcentaje de variación léxica presente en el javanés utilizado por emigrantes en la regencia de Dharmasraya Regency. Los datos se recopilaron mediante el método de observación y conversación. Se utilizaron los métodos de identidad y dialectométrico para analizar los datos. Los resultados muestran que el javanés en la regencia de Dharmasraya se divide en cuatro dialectos: Tebing Tinggi, Koto Laweh, Kurnia Koto Salak y Sitiung. El dialecto Sitiung se subdivide a su vez en dos subdialectos: el subdialecto Sitiung y el subdialecto Pulau Mainan. Estas diferencias dialectales son causadas por factores geográficos, la distancia entre los puntos de observación, el transporte y la comunicación. El javanés que se usa en la conversación diaria es diferente del javanés que se usa en el lugar de nacimiento o en la isla de Java, que no tiene un nivel de lenguaje y es conocido como unggah-ungguh. Esto sucede por la falta de dominio y de comprensión de los hablantes.

\section{Palabras clave}

léxico, variación, javanés, emigrante, dialecto

\section{Introduction}

Dharmasraya is one of the regencies in West Sumatera Province - Indonesia which has a multilingual community. The population does not only speak Minangkabau language, but also Javanese, Sundanese, and Batak languages in their conversation. From all those languages, Javanese has the second largest number of speakers in Dharmasraya, where $32,96 \%$ of the population are transmigrants from Java island (Pemerintah Kabupaten 2018)

Javanese language used in Dharmasraya is different from the one in Java island. In general, the Javanese language has the level that is known as unggah-ungguh. According to Sasangka (Indrayanto \& Yuliastuti 2015), unggah-ungguh is divided into two types unggah-ungguh ngoko (ngoko variations) and krama (krama variations). Ngoko variation is usually used by peers and by those who think themselves to have higher social status than the addressee. On the other hand, krama variation is used by those who think themselves to have lower social status than the addressee. However, unggah-ungguh is generally used only in special occasions in Dharmasraya. Krama variation is still used in 
the wedding ceremony and other events in Dharmasraya, but Javanese people there use ngoko variation in daily conversation. This Ngoko variation is used as the object of this research.

Abdullah in Oktaviani (2014) stated that local languages do not only develop in a particular historical setting but also change based on their interaction with a particular social environment that directly intersects one to another. The use of language will, therefore, mutually influence one another. Next, the development of local language is divided into three forms. First, it is caused by the interaction between local language itself which is resulted by direct converging of two areas, like what happens in the borderland. Second, interactions that occur due to mobility causes the emergence of groups of other language users in an area, like in the transmigration program. This is in line with the area that became the object of research, Dharmasraya Regency. Third, it happens because of the language development caused by the interaction between regional language and national language.

The presence of these transmigrants can automatically lead to the emergence of Javanese language usage among Minangkabau speakers. It certainly can trigger the emergence of language variations in Dharmasraya. Language variations can be studied through Dialect geography or dialectology. Dialect geography or dialectology is a field of linguistics that studies variations of language based on local differences (places) within a language area. Hence, the language variations discussed in this study is the lexical variation of Javanese language used by transmigrants in Dharmasraya.

The research questions are two: (1) What is the lexical variations of Javanese found in Dharmasraya?; and (2) What is the percentage level of different lexical variations in the Javanese found among points of observation in Dharmasraya?

This study is aimed at describing the lexical variations of Javanese of transmigrants found in Dharmasraya and determining the percentage of different lexical variations of Javanese found among points of observation in Dharmasraya.

The present study is expected to extend our knowledge of linguistics studies, especially dialect geography. This study also provides an important opportunity to maintain and preserve the language. Furthermore, this research is also important to 
advance the writers' knowledge in dialect geography studies of Javanese transmigrant language in Dharmasraya.

To date, several studies have investigated the Javanese language. Sunarso (2000), for instance, compared the forms of Javanese language - Krama - in Banyumas dialect with Krama in Yogyakarta-Surakarta dialect. He found that some of Krama words in Banyumas dialect were also found in Krama of the Yogyakarta-Surakarta dialect. Moreover, some of the Krama words in Banyumas dialect were found to be Ngoko in the Yogyakarta-Surakarta dialect. Banyumas dialect is influenced by Yogyakarta-Surakarta dialect which is a standard dialect, that is mostly spoken by a group of employees

Another study conducted by Sahayu (2003) who investigated phonological variations of Javanese language usage in the central city and the northern suburb of Grobogan Regency. The study suggests that the population in suburb area tends to use vocal phoneme $/ \supset /$ and $/ \varepsilon /$. However, the population in the central city tends to use $/ \mho /$ and /I/.

Rahayu (2012) discussed dialect variations of Javanese language in Ngawi Regency. The list of 250 lexicons was asked in this study. The findings showed 23 phonological variations and 47 lexical variations. From the phonological variation, it was found that the addition was done through a process of apheresis and syncope. Besides, there were also cluster and nasalization sound in several additions. Those variations were also found to be derived from the Indonesian language.

In another study, Kurniawan (2013) investigated phonological and lexical variations of Javanese language in Desapakem, Gebang sub-district of Puworejo District. The results showed that there were similarities and differences in pronunciation and lexicon between the Javanese language in Pakem village with standard Javanese language.

Kurniawati (2013) also discussed phonological and lexical dialect of Javanese language in Jogopaten village, Bulupesantren Sub-district of Kabumen Regency. The research results showed that there were phonological and lexical differences between the Javanese language in Jogopaten village and standard Javanese.

Different from previous studies, Junawaroh (2016) researched the phonological differences of languages in the western area of Central Java province. Her research showed that there were phonological differences of Javanese between Sundanese 
language in the western area of Central Java province. The differences were in the form of perfect correspondence, imperfect correspondence, and variations.

The studies presented thus far have similarities and differences with this research. The similarities are in terms of the approach used as this present study also uses the same dialectological approach. The similarity also lies in its object, which is the Javanese language. However, this research is different from those studies in terms of the place or research area. Although investigating a similar object of research, the Javanese language discussed in this research is transmigrants language, the language which is not used in the origin area. In this case, it discusses the Javanese language used among Minangkabau speakers.

\section{Method}

The data were collected through an observational method by observing language used by informants. Sudaryanto (1993: 137-138) stated that the basic technique of this method is tapping. An advanced technique of tapping consists of tapping while participating in a conversation as well as recording and noting techniques. In addition, a conversational method was also used to collect data. This method is called as 'conversational' because during the research the writers are having a conversation and direct contact with the language users (informants). According to Sudaryanto (1993: 137139), the basic technique of this method is persuading. The advanced technique consists of luring informants to speak first, recording, and noting technique.

The instrument used for collecting the data in this study was modified from Nadra \& Reniwati's book (2009). The instrument contains 864 questions that consist of lexicon concepts, morphemes, phrases, clauses, and sentences. This research took 708 questions comprising of 684 questions taken from Nadra \& Reniwati's book and 24 questions were intentionally made up by the writers to reveal the characteristics of each point of observation. Moreover, a list of questions in this study did not include the list of 
morphemes, phrases, clauses, and sentence questions. So, only the list of questions in the form of lexicon concepts was used based on the object of the study.

The research participants are Javanese speakers in Dharmasraya (15 informants); 3 informants for each point of observation. The informant criteria were chosen based on some conditions stated by Nadra \& Reniwati (2009: 37-40), such as aged 40-60 years, not highly educated (maximum junior high school), originated from the village or researched area, married to the person from the researched area, and had normal and complete speech organs.

The data were collected from five points of observation (PO); Tebing Tinggi village of Pulau Punjung districts (PO 1), Koto Laweh village of Koto Besar districts (PO 2), Sitiung village of Sitiung districts (PO 3), Kurnia Koto Salak village of Sungai Rumbai districts (PO 4), and Pulau Mainan village of Koto Salak districts (PO 5). The reasons of choosing these observations points are that those locations are the residence of Javanese transmigrants and the distance among them are quite far, so there will be infrequent communication among the transmigrants.

The research location can be seen in the following Map 1.

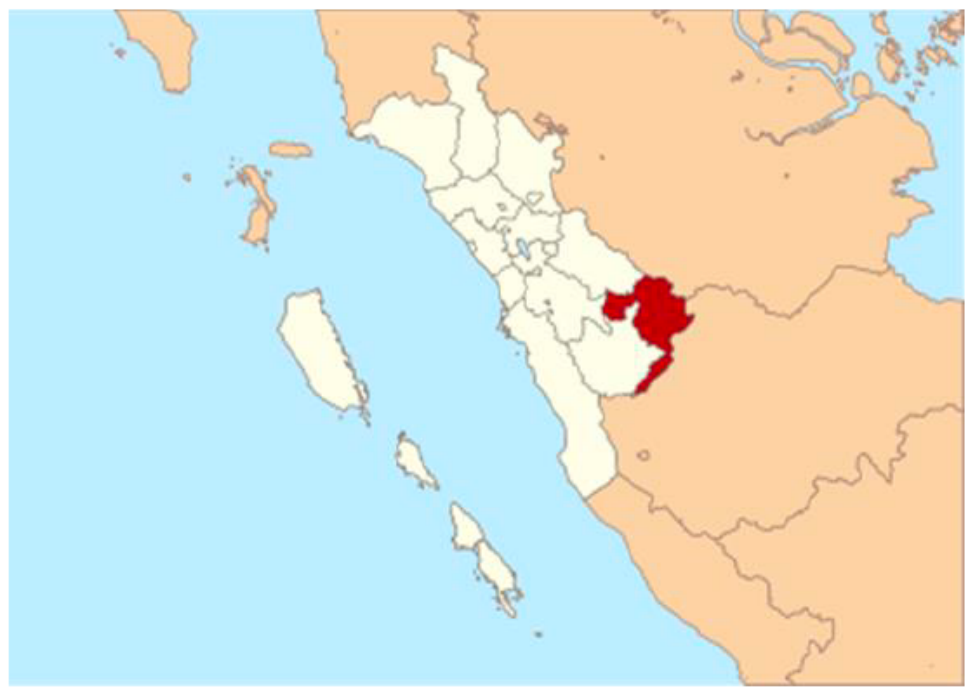

Map 1. Research Location in West Sumatera, Indonesia

Explanation:

$\square$ Dharmasraya Regency

(https://id.wikipedia.org/wiki/Berkas:Lokasi_Sumatra_ Barat_Kabupaten_Dharmasraya.svg) 
Identity method was used in data analysis stage by separating determinants technique and differentiating appeals technique as advanced techniques. This research also used the dialectometry method to calculate how many language differences found in the research area. This formula was also used to find the percentage of lexical variation in the points of observation and to determine the relationship between those points.

The formula is as follows:

$$
s \underline{x 100}=d \%
$$

$\mathrm{n}$

Notes:

$s=$ number of differences with other points of observation

$\mathrm{n}=$ number of comparable maps

$d=$ percentage distance of linguistic elements between points of observation

\section{Results and discussion}

The results of this study show that there are three hundred and forty-five concepts with lexical variations found from a list of seven hundred and eight questions asked. These are several examples of lexical variations presented in categories of numbers and sizes.

There are seven concepts which have lexical variations from twenty-seven lists of questions in the category of numbers and sizes. There are four concepts that have three lexical variations. This applies to the concept of "second" that has variations [keloro] is used in PO 4, [nomer loro] in PO 1 and PO 2, [pindo] in PO 3 and PO 5. The concept of

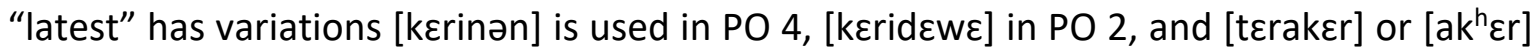
in PO 1, PO 3, and PO 5. The concept of "a length between thumb edge" has variations [sa? kilən] is used in PO 4, [sckilən] in PO 1, PO 2, and PO 5, and [scjenkəl] in PO 3. The concept "part of shares" has variations [bagean] is used in PO 3, PO 4, and PO 5, [sepețə?sepețə?] in PO 2, and [jatəh] in PO 1. 
Further, there are two concepts that have four lexical variations. This can be seen, for example, in the concept of "first" which has variations [plsanan] is used in PO 4, [nכmer sijl] in PO 2, [disck dewe] in PO 1, and [disek] in PO 3 and PO 5. The concept of "the biggest unit of rice measurement" has variations [kilinan] is used in PO 4, [sa? əクkən] in PO 2, [sa? vll] in PO 1 and PO 3, and [sa? bondot] in PO 5.

One concept that has five lexical variations is "the smallest unit of rice measurement". It has variations [tekeman] is used in PO 4, [sa? vll] in PO 2, [rongian] in

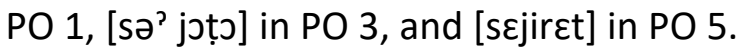

Next, there are some examples of lexical variations from various fields. For the concept of "eye" there are two lexical variations, namely [mripat] and [moto]. The form [mripat] is used in PO 1, PO 2, PO 3, and PO 4, while the form [moto] is used in PO 5.

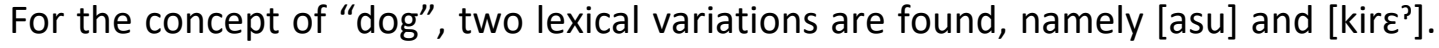
Lexicon [asu] is used in PO 1, PO 3, PO 4, and PO 5, while the lexicon [kirع $]$ ] is used in PO 2.

For the concept of "narrow", three lexical variations are found, namely [ciøt], [s\&sə?], and [copst]. The form [ciot] is used in PO 1 and PO 3, the form [sรsə?] is used in PO 2 and PO 5, while the form [copet] is used in PO 4.

The other example is the concept of "eating" found different lexicons in the five

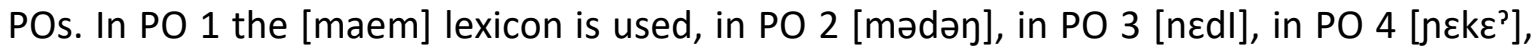
and in PO 5 [məyən].

After describing the different lexical variations, the data were calculated by the formula of dialectometry to see how far the percentage distance differences of linguistic elements among the points of observation. Here is the table of percentage results based on dialectometry calculation.

\begin{tabular}{|l|l|l|l|}
\hline Number & \multicolumn{1}{|c|}{$\begin{array}{c}\text { Points of } \\
\text { Observation }\end{array}$} & Differences & Percentage \\
\hline 1. & $1-2$ & 215 & $62 \%$ \\
\hline 2. & $1-3$ & 214 & $62 \%$ \\
\hline 3. & $2-3$ & 176 & $51 \%$ \\
\hline 4. & $2-4$ & 234 & $68 \%$ \\
\hline 5. & $3-4$ & 229 & $66 \%$ \\
\hline 6. & $3-5$ & 141 & $41 \%$ \\
\hline 7 & $4-5$ & 234 & $68 \%$ \\
\hline
\end{tabular}

Table 1. Percentage results of dialectometry calculation 
Based on the dialectometry calculation, the level of language variations among the points of observation found in the Javanese language in Dharmasraya Regency can be categorized into four dialects. The four dialects are (1) Tebing Tinggi dialect (in PO 1 area); (2) Koto Laweh dialect (in PO 2 area); (3) Kurnia Koto Salak dialect (in PO 4 area); and (4) Sitiung dialect (in PO 3 and PO 5 area). The Sitiung dialect, in particular, is separated into two subdialects, they are Sitiung subdialect (PO 3) and Pulau Mainan subdialect (PO 5). The four dialects can be seen in the following Map 2.

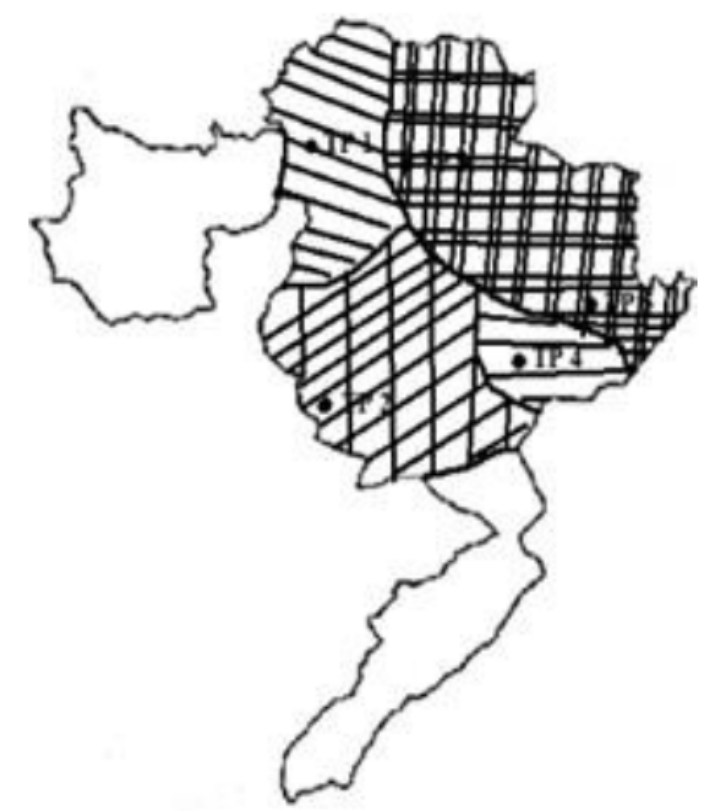

Map 2. Javanese Dialects in Dharmasraya Regency

Explanation:

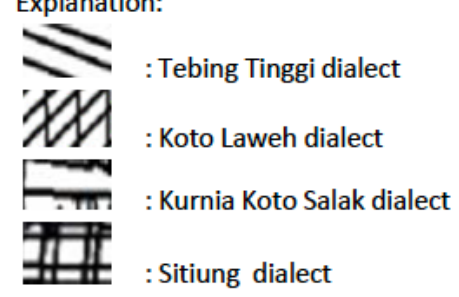

The highest percentage is found between PO 2 - 4 and PO $4-5$ for $68 \%$ and the lowest percentage is found between PO $3-5$ for $41 \%$. The two locations with the highest percentage are Koto Besar, Sungai Rumbai subdistrict, and Koto Salak subdistrict. The 
points of observation that have the lowest percentage are Sitiung and Koto Salak subdistrict.

The reason for the differences in the high percentage is because the geographical location of each point of observation is quite far. The travelling time between PO 1 and PO 2 takes approximately two and half hours by using a motorcycle, while it takes approximately one and half hours to travel from PO 2 to PO 4 . Besides, in order to reach the transmigrants area, especially PO 1 and PO 4 areas, the researchers must go through the forest. It happens because both of the areas are located in the suburbs area or far from the central city. On the other case, PO 2 is not only far away but also has a worse condition where there is no asphalt on the road so that the rider has to be more careful especially when it rains. There is an alternative route, but it should take a detour and also spend a long time to get there. The location of POs is far enough from the central city. The distance between the central city to PO 1 is $11 \mathrm{~km}, P O 2$ is $51 \mathrm{~km}$, and PO 4 is $59 \mathrm{~km}$. There is none of public transportation available in these areas. Most of the people have their own vehicles like a motorcycle to travel.

In terms of socialization, the speakers of each point of observation do not only communicate with the same Javanese people but also socialize with other tribes. They meet the other tribes only on special occasions, like in the traditional market, schools, health centres, and government offices. On that condition, they communicate by using the national language, Indonesian language. The communication between transmigrants in other points of observation is also rare to happen. It happens because the facilities and infrastructure at each point of observation are already sufficiently available, so they do not need to go elsewhere. In addition, the transportation is relatively difficult and also quite far to go to other areas. It is just if the teenagers want to study in Senior High school, they must move to the central city or subdistricts. The moment when the transmigrants meet each other, although it is not intensive, is at a wedding ceremony and in Eid al- Fitr. On that occasion, the transmigrant communities take advantage of the moment to chat and mingle with each other. The make use of this moment as they can only meet for quite a long time on those occasions.

Another factor that causes the differences in low percentage between PO 3 and PO 5 is the frequency of population in both POs to maintain the communication. They can 
keep communicating with each other because the route between the two areas is smooth and accessible. Meanwhile, the speakers in PO 4 and PO 5 are seldom to communicate with each other although the location of the two areas is close. Even though there is an alternative route between those POs, the people have to take a detour so the distance becomes further. Therefore, geographical factors, such as forests and sea and transportation factors, have a significant influence on the variation of language or dialects used so it affects the difference of percentage to become less or more.

The naming of the dialects is done based on the name of the researched areas. PO 3 and PO 5 are included in one dialect. The naming of this dialect is done based on the origin of the speakers in both of observation points, which historically come from Sitiung area. Therefore, the name of the dialect is Sitiung dialect. Sitiung dialect is separated into two subdialects: Sitiung subdialect and Pulau Mainan subdialect.

Language variations can be caused by several things, as described in the background. One of the reasons is the presence of other language speakers among Javanese speakers. Based on the linguistic situation that has been proposed, it is obvious that there are not only Javanese speakers but also other language speakers in Dharmasraya Regency, such as Minangkabau language, Sundanese language, and Batak language. However, based on the research that has been done, it can be concluded that the other language speakers are not affected by the Javanese speakers. It can be seen from the data gathered in this research. None of the data obtained from the PO is a variation from one of those languages. It happens because the Javanese speakers live in a community within transmigration area. They are entitled to the right of land where they occupy in the form of a land certificate in exchange for the land they have left in their place of origin. Living in groups make the socialization between the speakers only happen in particular places, such as in the traditional markets, schools, and other events. When socializing with Minangkabau speakers, they use the Indonesian language so that there is no influence of Minangkabau language found on the Javanese language.

Language levelling or better known as unggah-ungguh is still used in the area of points of observation, but only in the certain situations and conditions. Krama variation is still used in the wedding ceremony and other events in Dharmasraya. However, Javanese 
communities in Dharmasraya use ngoko variations for daily communication. Unggahungguh has not been noticed in their daily communication. This is due to lack of mastery or lack of understanding of the concept of krama variations. In addition, the social background of the family, e.g the father comes from outside Java and the mother comes from Java make it is possible that the Javanese language is not a top priority in speaking, especially to distinguish between krama and ngoko. It is different from Java island where unggah-ungguh is still used in any situation, even in the daily conversation. It happens because the people in Java are very concerned with the situational and social aspects of communication. The age, for instance, also affects in communication for which people have to use krama variations to speak with the elders. Therefore, it can be concluded that unggah-ungguh does not affect the variation of Javanese language in daily life in Dharmasraya Regency.

\section{Conclusion}

The results of this study indicate that there are three hundred and forty-five variations of concept found from a list of seven hundred and eight questions in the Javanese of transmigrants in Dharmasraya. The percentage of dialectometry calculation divides the levels of lexical variations in Javanese of transmigrant in Dharmasraya into four dialects; they are (1) Tebing Tinggi dialect (in PO 1 area); (2) Koto Laweh dialect (in PO 2 area); (3) Kurnia Koto Salak dialect (in PO 4 area); and (4) Sitiung dialect (in PO 3 and PO 5 area). Sitiung dialect is separated into two subdialects, namely Sitiung subdialect (PO 3) and Pulau Mainan subdialect (PO 5).

The different percentage of lexical variations is caused by geographical factors, the distance among the points of observation, transportation availability, and communication frequency between speakers. Javanese speakers in Dharmasraya do not seem to pay attention to unggah-ungguh in their daily conversations. It happens due to lack of mastery and understanding of the concept. 
Dialectologia 27 (2021), 175-187.

ISSN: 2013-2247

\section{References}

BERKAS: LOKASI SUMATRA BARAT KABUPATEN DHARMASRAYA.SVG (2019) Retrieved from <https://id.wikipedia.org/wiki/Berkas:Lokasi_Sumatra_Barat_Kabupaten_Dharmasraya.sv> GUITER, H. (1973) “Atlas et Frontière Linguistique”, Les Dialectes Romans de France, 930, 61-109. INDRAYANTO, B. \& K. YULIASTUTI (2015) “Fenomena Tingkat Tutur dalam Bahasa Jawa Akibat Tingkat Sosial Masyarakat", Magistra, 91 (XXVII), 37-44.

JunaWAROH, S. (2016) “Deskripsi Perbedaan Fonologi Bahasa-Bahasa di Wilayah Barat Provinsi Jawa Tengah", Humanika, 23, 1-8.

KurniaWAN, P. T. (2013) “Analisis Fonologi dan Leksikologi Bahasa Jawa di Desapakem Kecamatan Gebang Kabupaten Purworejo", Jurnal Pendidikan, Bahasa, Sastra, dan Budaya Jawa Universitas Muhammadiyah Purworejo, 4, 71-76.

KURNIAWATI, A. (2013) “Bentuk Fonologi dan Leksikon Dialek Bahasa Jawa Desa Jogopaten Kecamatan Bulupesantren Kabupaten Kebumen", Pendidikan, Bahasa, Sastra, dan Budaya Jawa Universitas Muhammadiyah Purworejo, 2, 19-23.

NAdRA, N. \& R. ReniWATI (2009) Dialektologi: Teori dan Metode, Yogyakarta: Elmatera Publishing.

Oktaviani, N. (2014) Bahasa Minangkabau di Kecamatan Pulau Punjung Kabupaten Dharmasraya, Padang: Skripsi Sarjana Fakultas IImu Budaya Universitas Andalas.

PEMERINTAH KABUPATEN (2018) Dahrmasraya. Retrieved from < http://www.dharmasrayakab.go.id>

RAHAYU, I. M. (2012) "Variasi Dialek Bahasa Jawa di Wilayah Kabupaten Ngawi: Kajian Dialektologi", Skriptorium, 2, 27-34.

SAHAYU, W. (2003) "Variasi Fonologis Pemakaian Bahasa Jawa di Pusat Kota dan Daerah Pinggiran Bagian Utara Kabupaten Grobogan", Humaniora, 3, 336-344.

SUdARYANTO (1993) Metode dan Aneka Teknik Analisis Bahasa: Pengantar Penelitian Wahana Kebudayaan secara Linguistik, Yogyakarta: Duta Wacana Univesity Press.

SUNARSO (2000) "Bentuk Krama Bahasa Jawa Dialek Banyumas dan Bahasa Jawa Dialek Yogyakarta-Surakarta: Sebuah Perbandingan", Humaniora, 1, 31-37. 